\title{
Efek Hipoglikemik dan Hepatoprotektif Fraksi Air Lingzhi (Ganoderma lucidum) pada Tikus Diabetes Mellitus
}

\author{
Siti Maimunah ${ }^{1^{*}}$, Dwiningsih ${ }^{2}$, Junaidi Khotib ${ }^{3}$ dan Sukardiman ${ }^{4}$ \\ ${ }^{1}$ Departemen Biomedik dan Klinis, UIN Maulana Malik Ibrahim, Malang, Indonesia \\ ${ }^{2}$ Departemen Biomedik dan Klinis, Universitas Setia Budi, Surakarta, Indonesia \\ ${ }^{3}$ Departemen Farmasi Klinis, Universitas Airlangga, Surabaya, Indonesia \\ ${ }^{4}$ Departemen Farmakognosi dan Fitokimia, Universitas Airlangga, Surabaya, Indonesia \\ *Corresponding Author. E-mail: maimunah841987@gmail.com
}

\begin{abstract}
This study is conducted to observe the hipoglicemic and hepatoprotective effect due to administration of water extract of lingzhi (G. lucidum) to aloxan monohydrate induced diabetic rats. The hepatoprotective effect was evaluated by histopathological view of the liver. Thirty-six rats devided into 6 groups, i.e: control, diabetic, glibenclamid comparing, and treatment group. Rats of the treatment group were administered by the water extract of G. lucidum with the dose of $225 \mathrm{mg} / \mathrm{kg} . \mathrm{BW}$. Within the 0 day, rats were intraperitoneal injected by the dose of $150 \mathrm{mg} / \mathrm{kg} . B \mathrm{~W}$. After persistent diabetic effect was appeared, glibenclamid or water fraction of G. lucidum were given 9 days respectively. In day 10, rats were dinecropsed for histopathological observation using haematoxylin/ eosin staining. The result of the study showed that water fraction of G. lucidum succesfully lowering blood-glucose level as well as glibenclamid does. Histopathological picture of liver tissue also reveal that water fraction of G. lucidum could protect liver from damage due to diabetic condition. That was proven by the morphological characteristics of hepatocyte through repair and recovery.
\end{abstract}

Keywords: Water fraction of lingzhi, G. lucidum, Diabetes Mellitus, Insulin resistance, hepatoprotective

\section{ABSTRAK}

Penelitian ini bertujuan mengetahui pengaruh pemberian fraksi air lingzi (Ganoderma lucidum) terhadap penurunan kadarglukosa darah dan gambaran histopatologi dijaringan heparpada tikus yang mengalami diabetes akibat induksi aloksan monohidrat. Sejumlah 36 ekor tikus dibagi dalam 6 kelompok, yaitu kelompok normal, kelompok diabetes, kelompok pembanding glibenklamid, dan kelompok fraksi air G. lucidum dengan dosis $225 \mathrm{mg} / \mathrm{KgBB}$. Pada hari ke-0 diberikan injeksi aloksan monohidrat $150 \mathrm{mg} / \mathrm{KgBB}$ secara i.p. Pemberian glibenklamid dan fraksi air G. lucidum selama 9 hari diberikan setelah timbul hiperglikemia yang persisten. Hari ke-10 setelah treatment tikus dikorbankan dan diambil jaringan heparnya untuk dilakukan pengujian histokimia menggunakan hematoxylin eosin. Hasil penelitian menunjukkan bahwa pemberian fraksi air G. lucidum dosis $225 \mathrm{mg} / \mathrm{kgBB}$ Lingzhi segar mampu menurunkan kadar glukosa darah yang hampir sama dengan kelompok tikus DM yang diberikan glibenklamid $0,45 \mathrm{mg} / \mathrm{KgBB}$ serta mampu melindungi jaringan hepar dari kerusakan karena kondisi DM. Ditunjukkan oleh perubahan morfologi sel hepatosit mengalami perbaikan.

Kata kunci : Fraksi air Lingzi, G. lucidum, Diabetes Melitus, Resistensi insulin dan Hepatoprotektif

Submitted: October $6^{\text {th }} 2021$ | Accepted: December $9^{\text {th }} 2021 \mid$ Published: December $31^{\text {st }} 2021$

\section{Pendahuluan}

Secara keseluruhan jumlah pasien yang terdiagnosa DM meningkat pada 20 tahun terakhir ini. Pada tahun 2000 sebanyak 151 juta jiwa di seluruh dunia terdiagnosa diabetes. Dengan peningkatan $6 \%$ pertahun, dilaporkan 221 juta jiwa menderita diabetes pada tahun 2010 dan akan meningkat menjadi 324 juta jiwa pada tahun 2025 [1]. Di Indonesia, Organisasi Kesehatan Dunia (WHO) melaporkan 8,4 juta jiwa pada tahun 2000 dan diprediksi akan meningkat menjadi 21,3 juta jiwa pada tahun 2030.

DM tipe 2 memiliki dua defek metabolik sebagai respon hiperglikemia: (1) resistensi jaringan target pada efek insulin, (2) ketidakmampuan sel $\beta$ pankreas untuk mensekresi insulin yang terencana pada resistensi insulin [2]. DM juga dikarakterisasi oleh resistensi insulin dan kurangnya sekresi insulin secara relatif dengan penurunan sekresi insulin secara progesif sewaktu-waktu. Resistensi insulin adalah gangguan jumlah insulin eksogenus atau endogenus untuk meningkatkan ambilan dan penggunaan glukosa [3]. Resistensi insulin terjadi dimana level produksi insulin dalam keadaan normal atau meningkat akibat respon biologi, biasanya menyebabkan melemahnya sensitivitas insulin untuk memediasi glukosa disposal. Efek metabolik resistensi insulin pada liver meningkatkan keluaran glukosa dengan meningkatkan glukoneogenesis [4].

Adanya aktivasi enzim yang berperan dalam proses glukoneogenesis dan glikogenolisis di hepar juga muncul dalam kondisi DM, sehingga produksi glukosa endogen meningka dan memperparah terjadinya komplikasi dari 
DM. Pada hepar juga terjadi peningkatan lipolisis sehingga menyebabkan ambilan asam lemak bebas meningkat sehingga dapat menyebabkan adanya simpanan trigliserida yang tinggi di hepar [5]. Resistensi insulin dan stres oksidatif merupakan kondisi yang sering berkaitan dengan gangguan hepar berupa Nonalcoholic Fatty Liver Disease (NAFLD).

Terapi DM diberikan pada penderita dengan target minimal dapat menurunkan kadar glukosa darah menjadi normal (aktivitas hipoglikemik). Selain itu terapi DM diharapkan juga mampu mengurangi resiko komplikasi karena DM, yaitu seperti penyakit kardiovaskular, seperti aterosklerosis, hipertensi, nefropati, neuropati, serangan jantung dan kebutaan [6]. Terapi yang digunakan saat ini adalah menggunakan penambahan insulin dari luar tubuh dengan sediaan insulin dan analognya yaitu obat oral antidiabetes (OAD). Mekanisme kerjanya OAD dengan memacu produksi insulin seperti derivat sulfonilurea, meningkatkan sensitifitas terhadap insulin dengan biguanida, menurunkan resistensi insulin dengan derivat thiazolidinedione, dan $\alpha$-glukosidase inhibitor yang dapat menurunkan kebutuhan insulin postprandial. Pengobatan tersebut responnya baik dan cukup berhasil, tetapi pemakaian dalam jangka panjang dapat menyebabkan timbulnya toleransi dan efek samping misalnya resistensi terhadap insulin, hipoglikemia, defisiensi vitamin B12 dan vitamin B6, edema, anemia, gangguan saluran cerna, dan penurunan $\mathrm{Ca}$ serum. Pemakaian obat oral antidiabetes juga dapat menimbulkan resistensi reseptor insulin [7].

Terapi antidiabetes biasanya digunakan dalam jangka waktu lama yang dapat mengakibatkan dapat mengakibatkan timbulnya efek samping. Dampak ekonomi pada DM jelas terlihat akibat biaya pengobatan dan hilangnya pendapatan, selain konsekuensi finansial karena banyaknya komplikasi seperti kebutaan dan penyakit vaskuler [8].

Ganoderma lucidum (G. lucidum) saat ini mulai dikenal sebagai terapi adjuvant pada pengobatan diabetes. Berbagai senyawa aktif terkandung dalam G. lucidum. Senyawa aktif tersebut antara lain: polisakarida, kompleks polisakaridapeptida, beta glukan, lektin, adenosin, triterpenoid, fenol, steroid, asam amino, lignin, misin, vitamin, nukleotida dan nukleosida yang masing-masing memiliki efek medicinal yang berbeda. Fraksi dari polisakarida lingzhi (G. lucidum) memiliki efek potensial aktivitas hipoglikemik yang telah di teliti pada studi hewan. Telah dilakukan studi klinik pada 71 pasien DM tipe-2 untuk mengevaluasi keamanan dan keberhasilan penggunaan fraksi dari ekstrak G. lucidum (Ganopoly). Pada studi tersebut menunjukkan bahwa Ganopoly memiliki toleransi dalam keamanan dan keberhasilan terapi dalam menurunkan konsentrasi glukosa darah (GD) [9].Beberapa penelitian yang telah dilakukan sebelumnya seperti pada penelitian Zhang et al., 2003 menyatakan bahwa pretreatment dengan polisakarida lingzhi (G. lucidum) menghasilkan efek antihiperglikemik pada tikus hiperglikemik yang diinduksi aloksan. Pada penelitian Cao et al. (2010), melaporkan bahwa polisakarida linzhi ( $G$. lucidum) dapat mengurangi dan menghambat absorbsi gula darah pada tikus [10].

\section{Metode Penelitian}

\section{Alat}

Alat yang digunakan dalam penelitian ini adalah kandang tikus dan perlengkapannya, sonde tikus, alat gelas, mortir dan stamper, seperangkat alat bedah, mikroskop dengan camera digital, kaca obyek, kaca penutup, botol kecil tempat jaringan, kertas label, alat tulis, disposable syringe, jarum suntik 26G, timbangan teknik, timbangan analitik, glucometer easy touch, rotary evaporator, water bath, microtome, peralatan untuk pembuatan dan pengamatan sediaan hispatologis, pewarnaan.

\section{Bahan}

Tanaman yang digunakan dalam penelitian ini adalah jamur lingzhi (G.lucidum) yang diperoleh petani jamur di Sukoharjo, Jawa Tengah. Jamur yang didapatkan dibersihkan dari kotoran atau tanah yang mungkin melekat dengan cara mencuci dengan air sampai bersih, lalu ditiriskan dari sisa air cucian, kemudian dikeringkan dalam oven suhu $40{ }^{\circ} \mathrm{C}$. Jamur kering dihaluskan menjadi serbuk, dan serbuk yang diperoleh selanjutnya digunakan untuk penelitian.

Air suling, water for injection, tablet glibenklamid, CMC Na (suspending agent), Larutan garam fisiologis, dapar formalin, bahan penginduksi DM (Alloxan monohidrat type lambda dari Sigma Aldrich), standar glukosa, $\mathrm{NaOH} 0,3 \mathrm{~N}, \mathrm{HCl}$ $1 \mathrm{~N}$, bufer Na2HPO4-NaOH (pH 11,5 mengandung $\mathrm{NaCl} 0,5$ $\mathrm{M})$, normal saline, neutral buffered formalin $10 \%$ dan bahan untuk pewarnaan jaringan pankreas (Haematoxylin-Eosin dari Baxter dan aldehyde fuchsin).

\section{Pembuatan Fraksi Air Lingzi (G. lucidum)}

Sebanyak $500 \mathrm{~g}$ serbuk G. lucidum dibersihkan dari polifenol dan monosakarida dicampur dengan 2,5 L etanol $80 \%(\mathrm{v} / \mathrm{v})$ pada suhu $30^{\circ} \mathrm{C}$ selama 24 jam sambil setiap kali dikocok, kemudian disaring. Residu dikering anginkan, setelah kering diekstraksi dengan air panas $100{ }^{\circ} \mathrm{C}(1: 20) \mathrm{w} / \mathrm{v}$. Filtrat dikentalkan dengan evaporator kemudian dipresipitasi dengan etanol $95 \% \mathrm{v} / \mathrm{v}$ pada suhu $4^{\circ} \mathrm{C}$ selama $24 \mathrm{jam}$. Hasil presipitasi di centrifuge (5000 rpm, 10 menit) dan presipitat yang di dapat di vakum freeze dried hingga didapatkan "crude tea poly saccharides".

Tabel 1. Kadar Glukosa Darah hewan uji kelompok normal dan diabetes yang diinduksi dengan aloksan

\begin{tabular}{ccccc}
\hline No & Kelompok & $\begin{array}{c}\text { Jumlah } \\
\text { Tikus } \\
\text { (ekor) }\end{array}$ & \multicolumn{2}{c}{$\begin{array}{c}\text { Kadar Glukosa Darah } \\
\text { (mg/dl } \pm \text { SD) hari ke- }\end{array}$} \\
\cline { 3 - 5 } 1 & Normal & 6 & $\begin{array}{c}117,18 \pm \\
11,92\end{array}$ & $\begin{array}{c}117,67 \pm \\
12,64\end{array}$ \\
\hline 2 & Diabetes & 30 & $117,00 \pm$ & $\begin{array}{c}274,00 \pm \\
15,11^{*}\end{array}$ \\
\hline
\end{tabular}

Hari ke-0 data kadar glukosa semua kelompok homogen $(\mathrm{p}=0,252)$

${ }^{\star}$ Hari ke-3 kadar glukosa berbeda secara signifikan terhadap kelompok normal $(\mathrm{p}<0,0001)$

\section{Uji Efek Hipoglikemik dan Histopatologi Liver}

Pemerikasaan kadar glukosa darah acak sebelum dilakukan pengujian. Pada hari pertama, kelompok hewan coba (kecuali kontrol normal) diinduksi aloksan monohidrat dengan dosis $150 \mathrm{mg} / \mathrm{kg}$ BB secara intraperitoneal, sebanyak sekali injeksi untuk menginduksi terjadinya DM. Perkembangan hiperglikemia tikus diperiksa pada hari ke- 3. Sampel darah diambil melalui vena caudalis di ekor tikus dengan cara mengiris tipis ekor tikus. Apabila setelah 3 (tiga) hari kadar 
glukosa darah tikus $>200 \mathrm{mg} / \mathrm{dl}$ maka tikus telah menjadi diabetes.

Hewan yang diabetes dikelompokkan menjadi 3 kelompok secara random (kontrol diabetes, pembanding, dan 3 kelompok perlakuan fraksi air G. lucidum). Hewan tanpa induksi aloksan digunakan sebagai kelompok kontrol normal. Masing-masing kelompok terdiri dari 6 ekor tikus.

1. Kelompok kontrol tikus normal (CMC Na 0,5\%)

2. Kelompok kontrol tikus diabetes (CMC Na 0,5\%)

3. Kelompok fraksi air lingzhi (G. lucidum) dosis $225 \mathrm{mg} /$ $\mathrm{KgBB}$

4. Kelompok pembanding glibenclamid $0,45 \mathrm{mg} / \mathrm{KgBB}$
Pemberian sediaan uji dilakukan pada hewan coba dengan metode kuratif selama 7 hari secara oral pada pagi hari setelah induksi aloksan. Kadar glukosa darah diukur hari pada hari ke0, 3, 5, 7, dan 10. Sampel darah diambil dari ekor dengan cara melukai ekor hewan coba. Kadar glukosa darah diukur dengan menggunakan easy touch glucometer.

Pada hari ke-10, setelah pengukuran glukosa darah, tikus dikorbankan dan dilakukan pembedahan serta pemotongan jaringan hepar tiap kelompok dengan mikrotom. Jaringan kemudian dipreparasi dengan melakukan fiksasi menggunakan neutral buffered formalin $10 \%$, setelah itu pemotongan dan pewarnaan secara histokimia dengan pewarnaan menggunakan Hematoxylin/eosin (HE).

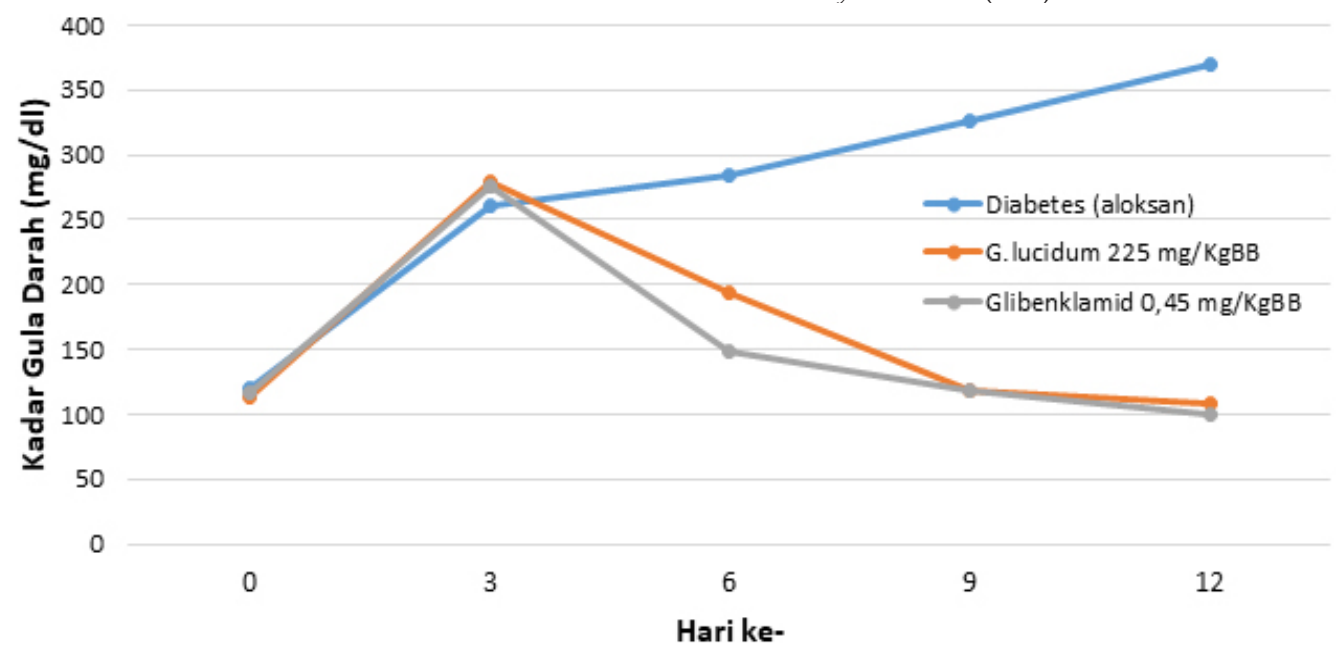

Gambar 1. Kadar Glukosa Darah hewan uji setelah pemberian fraksi air G.lucidum
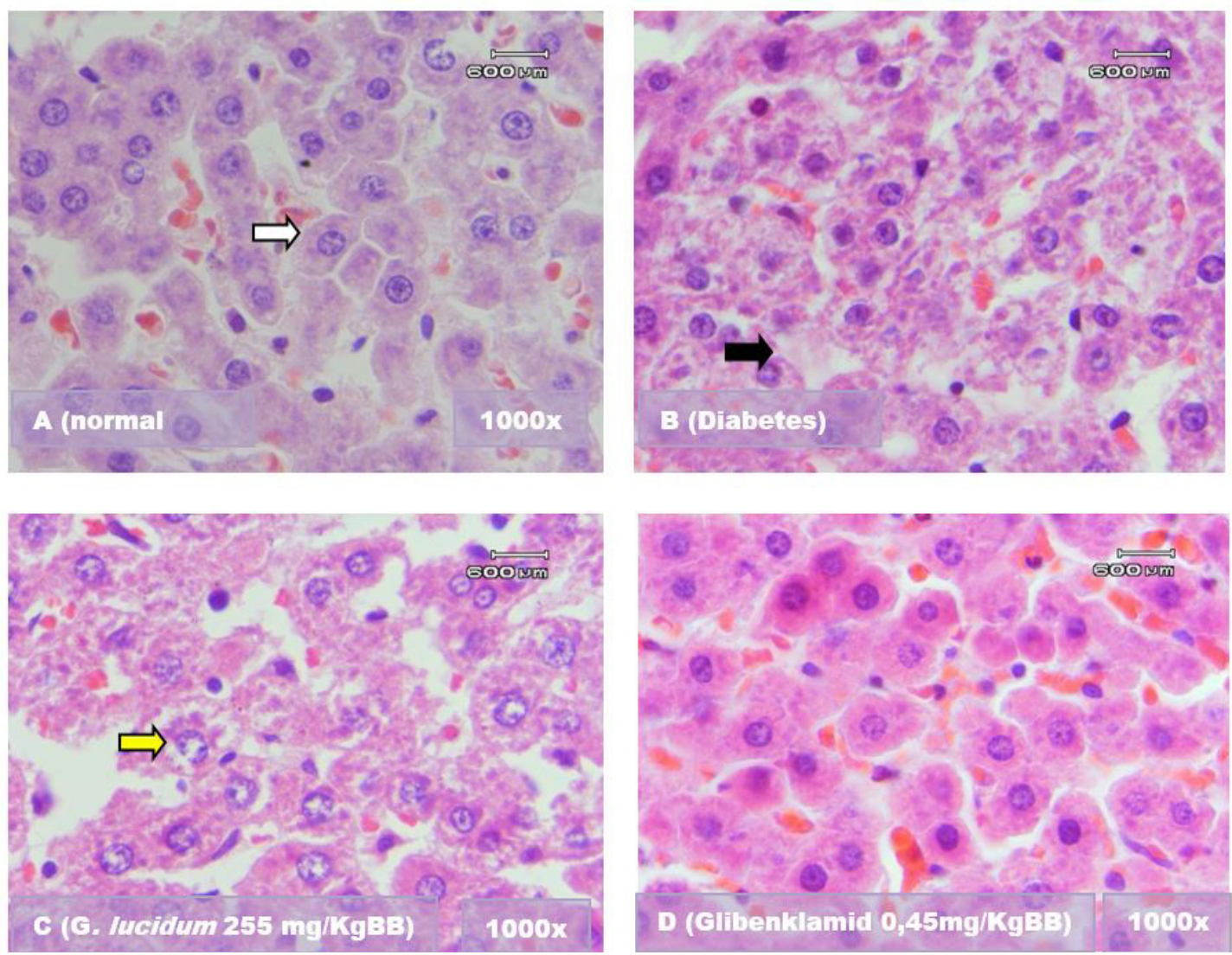

Gambar 2. Penampang melintang jaringan hepar dengan pewarnaan hematoxylin-eosin tikus normal(A); tikus DM(B);tikus yang mendapatkan fraksi air lingzhi (G. lucidum) dosis $225 \mathrm{mg} / \mathrm{KgBB}(\mathrm{C})$; tikus yang mendapatkan glibenklamid 0,45 mg/KgBB(E).

Keterangan: panah hitam=Dilatasi sinus; panah kuning=sel inti yang kosong; panah putih=sel inti utuh 


\section{Hasil dan Pembahasan}

Pada penelitian ini G. lucidum yang digunakan sebesar $1 \mathrm{~kg}$ jamur basah yang dikeringkan, diiris tipis-tipis dan didapatkan simplisia 343,6 gram. Pada irisan simplisia jamur dilakukan pemeriksaan organoleptis dan uji standarisi. Uji standarisasi juga dilakukan yaitu dengan penetapan susut pengeringan, penetapan rendeman fraksi dan penetapan kadar beta glukan dalam fraksi air. Penetapan susut pengeringan diperoleh hasil sebesar 34,36\%, sedangkan untuk penetapan rendeman fraksi dari 400 gram serbuk simplisia didapatkan sejumlah 6,98 gram (rendeman fraksi 1,75\%), dengan kandungan beta glukan dalam fraksi tersebut sebesar $\sim 35,68 \%$.

Pada penelitian ini digunakan tikus galur Wistar yang telah berumur 4-6 minggu sebanyak 20 ekor dan dibagi menjadi 6 kelompok dimana masing-masing kelompok terdiri dari 5 ekor tikus, yaitu kelompok normal (suspensi CMC Na 0,5\%) tanpa induksi aloksan monohidrat, kelompok diabetes yang diberikan suspensi $\mathrm{CMC} \mathrm{Na}$ dan kelompok diabetes yang diberikan terapi fraksi air G. lucidum dengan dosis 225 $\mathrm{mg} / \mathrm{kgBB}$ ) dan glibenklamid dengan dosis $0,45 \mathrm{mg} / \mathrm{kgBB}$. Pada hari ke-1 diberikan injeksi aloksan monohidrat $150 \mathrm{mg}$ / $\mathrm{kgBB}$ dalam larutan normal salin secara intra peritoneal untuk menginduksi DM. Kadar glukosa darah puasa diukur pada hari ke-3, apabila terjadi hiperglikemia (kadar glukosa darah $>250 \mathrm{mg} / \mathrm{dl}$ ) maka tikus dikelompokkan menjadi 5 kelompok diabetes dan diberikan larutan uji selama 9 hari. Kadar glukosa darah diukur pada hari ke 0, 3, 6, 9 dan 12, dan pada hari ke12 setelah dari pengukuran didapatkan kadar glukosa yang terkendali, tikus dikorbankan dengan cara dislokasi dan diambil jaringan heparnya.

Kadar glukosa darah tikus yang diinduksi dengan aloksan monohidrat pada hari ke-3 mengalami kenaikan yang bermakna dari $118,00 \pm 8,35 \mathrm{mg} / \mathrm{dL}$ menjadi $274,00 \pm 15,11$ $\mathrm{mg} / \mathrm{dL}$. Setelah diuji statistik diperoleh $\mathrm{p}<0,0001$ yang artinya bahwa injeksi aloksan mampu meningkatkan kadar glukosa darah secara bermakna dibandingkan kelompok normal pada hari ke-3. Kadar glukosa darah tikus pada hari ke-3 setelah mendapatkan injeksi aloksan dapat dilihat pada Tabel 1. Tampak bahwa kelompok tikus yang normal tidak mengalami perubahan kadar glukosa darah selama pemberian suspensi CMC Na 0,5\%. Kadar glukosa darah berkisar antara 106 - 136 $\mathrm{mg} / \mathrm{dl}$. Dapat disimpulkan bahwa usia tikus yang bertambah, jenis makanan yang diberikan, dan terapi (pengukuran kadar glukosa darah lewat ekor dan ketakutan hewan coba) yang diberikan selama masa perlakuan tidak memberikan perubahan fisiologis terhadap kadar glukosa darah tikus, sehingga pada data selanjutnya hanya akan dibahas kelompok tikus diabetes pada semua perlakuan.

Untuk mengetahui profil kadar glukosa darah dari seluruh kelompok perlakuan diketahui dengan melakukan analisis varian satu arah. Terlihat kelompok diabetes berbeda secara nyata dengan kelompok normal, pembanding (glibenklamid), dan fraksi air lingzhi (G. lucidum) $(\mathrm{p}<0,005)$. Hal ini dapat disimpulkan bahwa fraksi air G. lucidum mempunyai efek menurunkan kadar glukosa darah secara nyata.

Organ hepar merupakan organ target insulin dalam penyimpanan glukosa dalam bentuk glikogen. Keadaan DM akan mempengaruhi terjadinya perubahan morfologi jaringan organ tersebut. Untuk mengetahui perubahan morfologi jaringan hepar pada tikus pada keadaan DM, maka dilakukan pembedahan tikus dari semua kelompok untuk dipreparasi secara histokimia dengan potongan membujur dan pewarnaan hematoxylin-eosin (HE).

Hepar tikus normal menunjukkan sel-sel hepatosit polihedral yang tersusun rapat, batas yang jelas dan teratur dengan kapiler sinusoid yang jelas mengarah ke vena sentralis sebagai pusat. Hepatosit memiliki satu atau dua nukleus bulat dengan satu atau dua anak inti. Jarak nukleus antar hepatosit terlihat berjauhan. Pada tikus DM menunjukkan bahwa sel hepatosit tampak tidak teratur, batas antar sel tidak jelas dan inti sel yang gelap mengalami degenerasi dan nekrosis. Pada kelompok tikus diabetes dengan terapi fraksi air Lingzhi $(G$. lucidum) dosis $225 \mathrm{mg} / \mathrm{kgBB}$, sel hepatosit masih ada tetapi masih tidak teratur.

\section{Kesimpulan}

Berdasarkan hasil penelitian yang telah dilakukan, maka dapat disimpulkan bahwa pemberian fraksi air lingzhi $(G$. lucidum) dengan dosis $225 \mathrm{mg} / \mathrm{KgBB}$ mampu menurunkan kadar glukosa darah dan mampu memberikan perlindungan terhadap kerusakan jaringan hepar akibat diabetes melitus. Berdasarkan hasil penelitian ini, diharapkan dapat direkomendasikan menjadi alternatif terapi bagi penderita DM dengan mekanisme menurunkan resistensi reseptor insulin dan penghambatan glukoneogenesis. Tetapi diperlukan penelitianpenelitian lanjutan pada aplikasinya sebagai alternatif terapi pada pasien DM

\section{Daftar Pustaka}

[1] Zimmet P., Alberti K.G., Shaw J., 2001. Global and Societal implications of the diabetes epidemic. Nature, 414: $782-787$

[2] McPhee S.J. dan Hammer G.D., 2010. Disorders of the Endocrine Pancreas. Pathophysiology of Disease: An Introduction to Clinical Medicine, Sixth Edition, The McGraw-Hill Companies, Inc., Chapter 18

[3] Lebovitz H.E., 2001. Insulin resistance: definition and consequences. Clin Endrocinol Diabetes. 2001;109 Suppl 2:S135-48

[4] Wilcox, G., 2005. Review Article: Insulin and Insulin Resistance. Clin Biochem Rev. 2005 May; 26(2): 19-39

[5] Sundaram, R., R. Naresh, P. Shanthi, dan P. Sachdanandam. 2013. Modulatory effect of green tea extract on hepatic key enzymes of glucose metabolism in streptozotocin and high fat diet induced diabetic rats. Phytomedicine. 20(7): 577 584 .

[6] Golan, D.E., Tashijan, A.H., Armstrong E.J., and Armstrong, A.W.', 2008. Principles of Pharmacology The Pathophysiologic of Basis of Drug Therapy. 2nd Ed' Lippincott Williams and Wilkins. USA. p. 529-545

[7] Nolte, M.S., and Karam, J.H., 2001, Pancreatic Hormone and Antidiabetic Agent, In :'B.G., Katzung (Eds), Basic and Clinical

[8] Price, S.A. and Wilson, L.M., 2002. Gangguan sistem Patofisiologi Konsep Klinis Proses-Proses Penyakit. Ed. 6 Buku 1 dan 2. EGC. Jakarta.Pharmacology, 8th Ed, New York: Lange medical Book-Mc Graw Hill, p. 671-705.

[9] Deepalakshmi, K., dan Mirunalini, S., 2011, Review Article: Therapeutic Properties And Current Medical Usage O Medicinal Mushroom: Ganoderma Lucidum. International Journal of Pharmaceutical Science and Research. Vol. 2(8): 1922-1929

[10] Cao, H., dan Guo, X.Z., 2010, Therapeutic effects of Ganoderma Polysaccharide on type 2 diabetes in rats. Progress Mod. Biomed., vol.12, p. 96-102. 